DOI: 10.12957/demetra.2016.15976

\title{
A ética alimentar nos banquetes bíblicos: passagem, comunhão e poder
}

\section{Food ethics in bible banquets: passage, communion and power}

\author{
Raquel Santos Vitorino ${ }^{1}$ \\ Vanessa Nogueira Bezerra' \\ Michelle Cristine Medeiros da Silva' \\ Izayana Pereira Feitosa² \\ Hermano Machado Ferreira Lima ${ }^{3}$ \\ 'Universidade Federal de Campina Grande, Centro \\ de Educação e Saúde, Departamento de Nutrição, \\ Curso de Nutrição. Cuité-PB, Brasil. \\ ${ }^{2}$ Universidade Federal de Campina Grande, \\ Departamento de Educação, Curso de Psicologia. \\ Cuité-PB, Brasil. \\ ${ }^{3}$ Universidade Estadual do Ceará, Centro de \\ Humanidades, Departamento de Ciencias Sociais. \\ Fortaleza-CE, Brasil. \\ Correspondência / Correspondence \\ Raquel Santos Vitorino \\ Email: raquelvitorino_@ @hotmail.com
}

\section{Resumo}

Os banquetes, desde a Idade Antiga, oferecem elementos para reflexão sobre a passagem natureza-cultura operada via comensalidade no âmbito da culinária humana. E a Bíblia, enquanto obra literária, maior influência na formação da cultura ocidental, deixa pistas para a compreensão dos movimentos que instituíram tal prática de sociabilidade em torno da comida, bem como nos ajuda a refletir como eles ecoam em nossas práticas atualmente. Assim, este artigo objetiva compreender a ética constitutiva de banquetes descritos no texto bíblico, tendo como corpus a Bíblia. As análises do texto foram realizadas segundo a proposta de Bauer e Gaskell (2002). Os resultados apontaram para três tipos de comportamento que regiam os atos de partilha de alimentos: (1) a ética da passagem, que serve como signo de uma mudança na vida coletiva ou individual; (2) a ética da comunhão, que cria uma esfera de partilha de valores, conquistas, ideais, de cuidado em favor de alguém ou um povo, visando a um fim político; e (3) a ética do poder, partilhas que engendram relações de acordo, de demonstração do poder via produção de imagens de fartura e que desenham distinção entre soberano e súditos. Nessa ótica, pensar em alimentação envolve focar não apenas no componente nutricional, mas pensar os símbolos, a imaginação coletiva, a sociabilidade, enfim, as questões que perpassam o humano. Isso levanta desafios e a necessidade da construção de uma Antropologia da Nutrição.

Palavras-chave: Banquete. Comensalidade. Sociabilidade. Cultura. Religião. 


\section{Abstract}

Banquets, since ancient times, have offered elements to reflect on the passage from nature to culture operated via commensality within the human cuisine. And the Bible as a literary work, the greater influence on the formation of Western culture, leaves clues for understanding the movements that have instituted the practice of sociability around food, helping us to reflect how they echo in our current practices. Thus, this article aims to understand the ethics constituting banquet described in the biblical text, taking the Bible as corpus. Text analyzes were performed according to the proposal of Bauer and Gaskell (2002). The results pointed to three types of behavior governing the acts of food sharing: (1) the ethics of passage, which serves as a sign of change in collective or individual life; (2) the ethics of communion, which creates a sphere of shared values, achievements, ideals, care favoring someone or a people, aiming at a political end; and (3) the ethics of power, sharing that engenders relations agreement, demonstration of power via the production of plenty of pictures and drawing distinction between sovereign and subjects. From this perspective, thinking of food involves focusing not only on the nutritional component, but thinking of the symbols, the collective imagination, sociability - in short, issues that pervade the humanity. This raises challenges and the need to build an Anthropology of Nutrition.

Key words: Banquet. Commensality. Sociability. Culture. Religion.

\section{Introdução}

Toda linguagem, além de um valor racional e funcional, contém seus ruídos, desvios e aspectos simbólicos. Assim também é a alimentação que, para além seu componente nutricional, reveste-se de cultura, sociabilidade e de aspectos da subjetividade humana.

Segundo Canesqui, "o alimento além de seu caráter utilitário, constitui-se em uma linguagem”. São enfocados os seguintes rituais: o início e a manutenção das relações pessoais e de negócios, a expressão de amor e carinho, a distinção de um grupo, a reação a um estresse psicológico ou emocional, o significado de status social ou de riqueza, de recompensas ou castigos, reconhecimento, 
fortalecimento da autoestima, exercício do poder político e econômico, prevenção e tratamento de enfermidades físicas e mentais, mudanças de hábitos. Todos esses são eventos relacionados e marcados pelo consumo de alimentos em uma rede de sociabilidades. ${ }^{2}$ Esse componente social que habita o ato de comer e beber em comunidade define a comensalidade. Mensa, do latim, significa conviver à mesa e isto envolve não somente o padrão alimentar ou o que se come mas, principalmente, como se come. ${ }^{3}$

E o que poderia ser dito sobre os rituais de comensalidade em um dos livros que, segundo Sellier, ${ }^{4}$ mais influenciaram a formação da cultura ocidental: a Bíblia? Tomando este referencial como ponto de partida, além da afirmação do antropólogo Claude Lévi-Strauss, ${ }^{5}$ que acredita que a literatura enquanto forma de arte pode ser tomada como modelo reduzido para compreensão da cultura, é que nascem as questões que animam este trabalho: que ética estrutura os banquetes narrados no texto bíblico? Como essa ética ecoa nas nossas práticas alimentares atualmente?

O presente artigo, portanto, tem o objetivo de compreender a ética constitutiva de banquetes descritos no texto bíblico.

\section{Metodologia}

Neste artigo, a Bíblia é tomada como texto literário. ${ }^{6}$ Sua escolha - em um trabalho que tenta compreender o fenômeno cultural da comensalidade - justifica-se, pois, esta é uma das obras, ao lado das narrativas mitológicas gregas e dos escritos do direito romano, mais lidas no mundo e que influencia em sobremaneira a cultura ocidental, conforme destaca Sellier. ${ }^{4}$

O corpus específico de análise é delimitado pelo Velho Testamento (VT), de Gênesis ao Livro de Malaquias; e os quatro evangelhos do Novo Testamento (NT), do Evangelho de Mateus a João. Foi analisado partir da metodologia de análise temática, que é um tipo de análise de conteúdo. De acordo com Bauer \& Gaskell, ${ }^{7}$ a análise temática é um procedimento gradual de redução do texto qualitativo.

Inicialmente, realizou-se a primeira redução, em que os textos foram parafraseados em sentenças mais sucintas. Após isso, efetuou-se uma segunda redução, na qual as sentenças foram parafraseadas em palavras-chave. "Ambas as reduções operam com generalização e condensação de sentido". ${ }^{7}$ 


\section{Resultados e Discussão}

Os banquetes bíblicos fornecem inúmeros exemplos de como a vida antiga estava centrada em torno das refeições. Em relação à questão inicial deste trabalho - que a ética é fundada a partir desses banquetes -, puderam ser classificadas algumas linhas de reflexão: a Ética da Passagem, a Ética da Comunhão e a Ética do Poder. Isso, ademais, nos fez criar uma reflexão sobre a conduta do homem em relação a suas práticas alimentares exercitadas na contemporaneidade.

\section{Ética da Passagem}

Pode-se dizer que são movidos por uma ética da passagem os banquetes que, inseridos no sistema alimentar a apresentado no texto, pontuam momentos de transição e configuram-se como atos simbólicos sublinhados pelas práticas alimentares, tendo como principal objetivo marcar uma mudança na vida de um indivíduo ou coletividade. Assim podemos compreender, a partir da ideia de passagem, de Van Gennep ${ }^{8}$ :

[...] é o próprio fato de viver que exige às passagens sucessivas de uma sociedade especial a outra e de uma situação social a outra, de tal modo que a vida individual consiste em uma sucessão de etapas, tendo por término e começo conjuntos da mesma natureza, a saber, nascimento, puberdade social, casamento, paternidade, progressão de classe, especialização de ocupação, morte. ${ }^{8}$

a Segundo Fischler (1995), sistema alimentar são representações, crenças e práticas que estão associadas a ele e que os indivíduos que formam parte de uma cultura ou de um grupo no interior desta cultura partilham. Cada cultura possui uma cozinha específica que implica classificações, taxonomias particulares e um conjunto complexo de regras que atendem não apenas à preparação e combinação de alimentos, mas também a sua colheita e consumo.

FISCHLER, Claude. El (h)omnívoro: El gusto, la cocina y el cuerpo. Tradução de Mario Merlino. Barcelona: Editorial Anagrama, 1995, p.34. 
No corpus analisado, foram encontrados banquetes que explicitam a ética da passagem: como os banquetes de casamentos, aniversários e os fúnebres (quadro 1).

Quadro 1. Ética da passagem

\begin{tabular}{|c|c|c|c|c|c|}
\hline $\begin{array}{l}\text { Livro, } \\
\text { capítulo e } \\
\text { versículo }\end{array}$ & $\begin{array}{l}\text { Tipo do } \\
\text { banquete }\end{array}$ & Anfitrióes & Razão do banquete & $\begin{array}{l}\text { Público } \\
\text { convidado }\end{array}$ & $\begin{array}{l}\text { Alimentos/ } \\
\text { preparações } \\
\text { consumidos }\end{array}$ \\
\hline $\begin{array}{l}\text { Gênesis } \\
29: 22\end{array}$ & Casamento & Labão & $\begin{array}{l}\text { Comemorar o enlace } \\
\text { matrimonial entre Jacó } \\
\text { e Raquel. Negociação } \\
\text { entre Labão e Jacó }\end{array}$ & $\begin{array}{l}\text { Família e } \\
\text { amigos }\end{array}$ & Não relatado \\
\hline Ester 2:18 & Casamento & Assuero & $\begin{array}{l}\text { Comemorar o enlace } \\
\text { matrimonial entre } \\
\text { Assuero e Ester }\end{array}$ & $\begin{array}{l}\text { Todos os } \\
\text { cidadãos da } \\
\text { cidade }\end{array}$ & Não é relatado \\
\hline $\begin{array}{l}\text { Gênesis } \\
40: 20\end{array}$ & Aniversário & Faraó & $\begin{array}{l}\text { Comemorar o } \\
\text { nascimento do Faraó. } \\
\text { Assassinato do padeiro }\end{array}$ & $\begin{array}{l}\text { Todos os } \\
\text { cidadãos da } \\
\text { cidade }\end{array}$ & Não relatado \\
\hline Marcos 6:21 & Aniversário & Herodes & $\begin{array}{l}\text { Comemorar o } \\
\text { nascimento de Herodes. } \\
\text { Assassinato de João } \\
\text { Batista }\end{array}$ & $\begin{array}{l}\text { Príncipes } \\
\text { da Galiléia }\end{array}$ & Não é relatado \\
\hline $\begin{array}{l}\text { Samuel I } \\
25: 36\end{array}$ & Fúnebre & Nabal & $\begin{array}{l}\text { Comemorar sua vitória } \\
\text { sobre Davi }\end{array}$ & Nabal & Não é relatado \\
\hline
\end{tabular}

As primeiras menções aos matrimônios, na história ocidental, aparecem nos textos bíblicos. Nesses relatos, os cônjuges eram expostos a algum ritual religioso para oficializar o enlace. Aqui serão destacados pelo menos dois fragmentos que se referem à passagem dos matrimônios: o casamento de Jacó e Raquel e o casamento do rei Assuero e Ester. Duas cerimônias com diferentes propostas, mas com a mesma finalidade: celebrar o contrato matrimonial. ${ }^{\mathrm{b}}$

Jacó, filho de Rebeca, quando chegou a Harã,conheceu e se apaixonou por sua prima, a pastora Raquel, filha de Labão, irmão de sua mãe. Diante disso, ele prometeu servir a seu pai por sete anos para tê-la como esposa. Após o prazo estabelecido, entretanto, Labão não cumpriu o combinado:

b De acordo com Souza (2008), a constituição do casamento civil é um contrato entre Estado e duas pessoas, com o objetivo de constituir família. Conforme Costa (2007), o casamento religioso é uma celebração em que se estabelece o vínculo matrimonial das regras de determinada religião. Este se submete às regras da respectiva religião e independe do seu reconhecimento pelo Estado ou pela lei civil para ser válido. 
ao invés de Raquel, entregou para o casamento Lia, a filha mais velha, visto ser de costume casar a filha mais velha antes da mais nova. Jacó, então, serviu a Labão por mais sete anos para enfim ter Raquel ao seu lado. Dessa vez, no entanto, quando os anos se completaram, Labão concedeu a mão de Raquel. Para selar cada um dos casamentos, Labão ofertou banquetes públicos entre amigos e familiares oficializando seu acordo com Jacó.

Já no segundo caso, tem-se o exemplo do banquete que marca o matrimônio do rei Assuero com Ester. Este, por sua vez, após afastar Vasti como rainha do seu reinado, vai em busca de uma nova esposa. A escolhida foi Ester, uma jovem cheia de formosura. Ester encantou o rei Assuero e o próprio sabia que a presença de uma nova rainha em seu reinado demonstraria mais confiança para o povo. Foi realizada uma cerimônia de casamento, selada publicamente com um banquete para todos os cidadãos de Susã. Tal repasto convivial ficou conhecido como o Banquete de Ester, onde o rei distribuiu presentes segundo sua generosidade.

Como se pode perceber, os casamentos, já no relato bíblico, tinham como função marcar uma passagem que, mais do que um laço afetivo, constituía um contrato, um negócio realizado a conselho de seus pais, tutores ou ancestrais (Labão, Mardoqueu ou Mordecai, este último primo e tutor de Ester).

O principal papel do casamento, portanto, era servir de base a alianças cuja importância se sobrepunha ao amor e à sexualidade. ${ }^{9}$ Labão procurava uma ética comunitária com o casamento de Jacó e Raquel; Assuero desejava assegurar seu poder, manter os limites territoriais e perpetuar sua linhagem; Mordecai, por sua vez, preocupado com o destino do povo judeu, pautou-se pela ética judaica: por um lado, a fidelidade ao rei da terra na qual vive e, ao mesmo tempo, a reafirmação de quem ele é e qual a responsabilidade que lhe cabe por isso. Sendo assim, soube dar a Ester as orientações adequadas para a consolidação desta passagem: de judia deportada a Imperatriz da Pérsia.

Por que a necessidade de marcar essa passagem contratual com comida? Oferecer e compartilhar comida, nesses casos, poderia simbolizar o desejo de criar laços. ${ }^{10}$ A comensalidade, então, funciona como um sinal da aceitação da participação do indivíduo em determinado círculo social: uma nova família, um novo povo. ${ }^{11}$ Os convidados são convocados a comungar deste pão como copartícipes deste jogo de interações sociais, tendo em vista a necessidade de tornar público o contrato firmado. A passagem explicita-se.

Algo interessante a considerar é que não se sabe ao certo o que se consumia nos banquetes de casamentos bíblicos. A exceção em termos de descrição de alimentos aparece no episódio bíblico marcado pelo milagre de multiplicação do vinho, no episódio conhecido como as Bodas de Canãa.

Portanto, em se tratando de banquetes, percebe-se que há no texto bíblico um desejo de revestir os alimentos de um caráter sagrado. O vinho, por exemplo, é um alimento que, juntamente com o pão e o azeite, foram revestidos de caráter sagrado e litúrgico pela Igreja. ${ }^{12}$ No embate contra a 
gula, sacralizar tais alimentos seria uma forma de blindá-los enquanto objetos de desejo. A gula é um dos pecados capitais. Quellier ${ }^{13}$ mostra que, entre todos os pecados capitais, a gula étida pela Igreja como aquele mais grave, visto que incita aos outros vícios carnais, principalmente à luxúria. Desejar a comida para além de sua função de subsistência seria o primeiro passo para incorrer em pecado.

Sobre esta afirmação, pode-se mencionar a narrativa relativa ao maná oferecido aos judeus. Tal como é narrado no livro do Êxodo, o maná refere-se ao "pão do céu”(Exôdo 16), o alimento diário dado por Deus ao povo de Israel durante os quarenta anos da sua travessia pelo deserto em direção à Terra Prometida.

Podem-se demarcar algumas características comuns entre os casamentos mencionados anteriormente: eram ofertados ao público, em geral aos familiares próximos, amigos e comunidade, tendo como anfitriões os sujeitos da passagem e/ou os pais dos noivos. Os banquetes de casamentos atuais guardam algumas semelhanças com tais festejos: continuam sendo ofertados para pessoas próximas, sendo momentos para marcar socialmente esta passagem contratual. A decoração, as atrações, a culinária e vestimentas para a ocasião foram se adaptando ao tempo que são realizados, dependendo da cultura. Em geral, os grandes banquetes de casamento são distintivos de luxo e marcam socialmente a união de famílias abastadas. ${ }^{14}$

Os casamentos são modelos de ética de passagem, porque representam uma mudança expressa na vida social de duas pessoas. São passagens idênticas para ambos e com um único objetivo: atravessar a etapa do estado de noivos para casados. É um dos ritos mais importantes para a sociedade na vida e a partilha comum de alimentos atesta essa mudança. A comensalidade promove uma forte e expressiva convivialidade em circunstâncias particulares. Congrega pessoas por ocasião dos ritos de passagem, nomeadamente, o nascimento e o casamento. ${ }^{15}$ Portanto, o consumo de alimentos neste caso é ritual, sendo o rito algo que coloca ordem, classifica, estabelece prioridades, dá sentido do que é importante e do que é secundário. ${ }^{16}$

Outro ritual de passagem marcado por banquetes são as comemorações dos natalícios, ou seja, os aniversários. Destaque no texto bíblico para o aniversário do Faraó egípcio e para o aniversário de Herodes.

O Faraó, o rei do Egito, após ser ofendido pelo seu copeiro e padeiro, mandou prendê-los. O copeiro e o padeiro tiveram sonhos; José, filho de Jacó, relevou seus significados. O copeiro disse a José que tinha visto uma videira da qual brotaram três ramos com cachos de uva. As uvas amadureceram e ele as espremeu no copo de Faraó. Com a ajuda de Deus, José logo entendeu o significado desse sonho, e disse ao copeiro que os três ramos significavam três dias e que, após esse tempo, o Faraó lhe daria novamente o cargo de copeiro. Da mesma forma, José interpretou os sonhos do padeiro: havia três cestos de pães sobre a cabeça dele, bem como aves que comiam o que havia em um dos cestos. A resposta desse enigma foi revelada a José, que trouxe à tona a 
interpretação: os três cestos são três dias. Daqui a três dias, o Faraó te levantará a cabeça de cima de ti e certamente te pendurará numa madeira e as aves irão comer a tua carne de cima de ti. E da forma que foi dita aconteceu: o copeiro foi reposto a copeiro chefe e o padeiro foi assassinado: "e aconteceu ao terceiro dia, o dia do nascimento do Faraó, que fez um banquete a todos os seus servos; e levantou a cabeça do copeiro-mor, e a cabeça do padeiro-mor, no meio dos seus servos" (Gênesis 40:20).

Já na comemoração do aniversário do rei Herodes, sua filha, Salomé, se apresentou ao rei e demais convivas. Após sua apresentação, o rei prometeu-lhe qualquer coisa que pedisse. A moça, orientada pela mãe, disse ao rei que desejava a cabeça de João Batista. O rei concedeu tristemente o pedido. Perante outras autoridades e líderes da Galiléia, a cabeça de João Batista foi servida em um prato:

Pediu ao rei, dizendo: Quero que imediatamente me dês num prato a cabeça de João o Batista. E o rei entristeceu-se muito; todavia, por causa do juramento e dos que estavam com ele à mesa, não lha quis negar. E, enviando logo o réu o executor, mandou que lhe trouxessem ali a cabeça de João. E ele foi, e degolou-o na prisão; E trouxe num prato, e deu-a a menina, e a menina a deu a sua mãe (Marcos 6, 25:28).

Os aniversários citados nas passagens bíblicas chamam atenção para o trágico: o assassinato de duas pessoas em um momento de festejo natalício. O copeiro e João Batista foram vítimas do poder dos seus reis, uma ação nada incomum na Idade Antiga. O tom trágico dos aniversários coloca a passagem do nascimento frente a frente com a passagem fúnebre.

Os textos bíblicos não especificam o que se comia ou bebia por ocasião desses aniversários, mas acredita-se que o costume de consumir guloseimas durante o festejo remonte à Antiguidade, tendo sua provável origem nas festas de culto aos deuses daquela época. Atribui-se à Deusa Ártemis, celebrada pelos gregos como a matrona da fertilidade, pelo aparecimento de uma espécie de bolo de aniversário. Ele éprovavelmente a evolução de um preparado de mel e pão, no formato de uma lua, que fiéis levavam ao famoso templo em homenagem a ela em Éfeso, antiga colônia grega na Turquia atual. Já o uso de velas também teria sido herdado do culto aos deuses antigos, que tinham a missão de levar, por meio da fumaça, os desejos e as preces dos fiéis até o céu, para que eles fossem atendidos. ${ }^{17}$ Todavia, a tradição estrita do bolo e das velas conforme conhecemos originou-se no século XVIII, na Alemanha. ${ }^{18} \mathrm{~A}$ vela ainda mantém a mesma intenção: realizar o pedido do aniversariante; já o bolo ganhou o significado de alimento mais importante de comemoração daquela passagem.

Festas de aniversários não são relacionadas, em grande parte do mundo, com qualquer espécie de religião, ao contrário do casamento, que passou a ser um ato de grande relevância religiosa nos últimos séculos. 
Algumas religiões, como as testemunhas de Jeová, inclusive, não celebram aniversários. Os adeptos deste credo levantam algumas razões para isso: (1) a origem dos aniversários é pagã; (2) os primeiros cristãos não comemoravam aniversários; (3) a única celebração a ser observada pela Bíblia é a comemoração da morte de Cristo; (4) a Bíblia não comenta que servo algum de Deus tenha comemorado aniversário, ao contrário, ela só apresenta duas únicas passagens, em todo o livro, onde ocorrem assassinatos. Tal fato, mais que uma omissão, seria um indicativo divino de que tais festas não deveriam ser celebradas. Evitam ainda cumprimentos, visitas aos parentes no dia de seus aniversários e festejos pessoais.

Outro tipo de ritual de passagem que merece ao menos ser mencionado é o ritual fúnebre. No início do Paleolítico, o contato do homem com a divindade, com o sobrenatural, foi instituído. Esse fato é reconhecido por uma nova forma de sepultar os mortos..$^{19}$ Os seres humanos, procurando manter um elo com o mundo divino, sempre cercaram seus mortos com cerimônias dos mais variados tipos.

Mithen ${ }^{19}$ também afirma que o processo de sepultamento, seguido de rituais, sinaliza uma alteração no pensamento dos primeiros homens modernos em relação aos arcaicos. Os primeiros homens modernos passaram a sepultar seus mortos promovendo ritos fúnebres que utilizavam o totemismo, com carcaças ou imagens de animais depositadas nos túmulos, caracterizando o morto com peculiaridades do animal em questão. Havia também a destruição de objetos e animais pertencentes ao morto, em sinal da sua perda e do sofrimento dos seus. Seguindo a entrega dos presentes em sacrifício, ocorria o banquete, outro estágio do ritual fúnebre.

O banquete, em um período longo da Antiguidade, era consumido e preparado ao lado da pira ou do sepulcro do morto, mas em certo momento da história passou a ser preparado em casa e consumido à mesa, onde as pessoas imaginavam que o morto se encontrava presente. Após o banquete, aconteciam os jogos fúnebres. Estas competições ocorriam para celebrar e honrar o falecido, além de estabelecer uma função social, característica dos rituais mortuários. Os jogos também serviam para obtenção de prestígio, pois quanto mais honra recebia o morto, mais importante ele era. ${ }^{20}$

A celebração da Páscoa também é uma celebração fúnebre, por comemorar não a vinda de uma vida ou a união de duas pessoas, mas a passagem de vida para morte de Jesus Cristo. A própria palavra "Páscoa" significa "passagem" e não "paixão", como muitos acreditam.

Na Antiguidade, a Páscoa era festejada com a representação da libertação do povo de Israel, que ficou em cativeiro sob domínio egípcio. A refeição pascal era realizada com ervas amargas, pães ázimos e cordeiro assado. Cada alimento tem em si um significado: ervas amargas representavam o amargor da vida do povo durante a escravidão no Egito; pão ázimo, a pressa de fugir em viagem; uvas e trigo, sinal de prosperidade; leite e mel, as promessas de Deus de uma terra boa; frutas doces, 
representando a ação de Deus em favor dos oprimidos; água com sal, representando o suor do povo na execução do trabalho forçado; ovo cozido, símbolo de resistência frente às forças opressoras. ${ }^{21}$

A partir do conhecimento do Novo Testamento e da realização da última ceia de que Jesus participou, a Páscoa passou de celebração da libertação do povo de Israel para a celebração a memória de Cristo e sua passagem na Terra. O dia da Páscoa é o aniversário de morte de Cristo. Entretanto, para os judeus - ainda nos dias atuais - a memória da Última Ceia é um marco da libertação da escravidão do povo de Israel do Egito.

No corpus da pesquisa, além disso, o banquete que Nabal preparou para si mesmo após uma discussão com Davi culmina com a morte do vil Nabal, como refere o relato bíblico. Talvez como um lembrete ao pecado da gula, Nabal falece após se fartar de tanta comida e bebida:

E, vindo Abigail a Nabal, eis que tinha em sua casa um banquete como de rei; e o coração de Nabal estava alegre nele, e ele jámuito embriagado, pelo que ela não lhe deu a entender coisa alguma, pequena nem grande, atéa luz da manhã. Sucedeu, pois, que pela manhã, estando Nabal jálivre do vinho, sua mulher lhe deu a entender aquelas coisas; e se amorteceu o seu coração, e ficou ele como pedra. (Samuel I, 25:36-37).

Aniversários e rituais fúnebres compõem a ética da passagem devido à mudança de mais uma etapa da vida. Aniversários, a celebração de mais um ano de vida marcada por um ritual comum e individual que uma pessoa atravessa a cada ano; rituais fúnebres, a passagem mística de etapa de vida física para uma não física.

Os ciclos cerimoniais pelos quais o homem passa em toda as circunstâncias de sua vida sempre acabam tendo um objetivo ou coletivo ou individual, como podemos ver nas passagens realizadas em casamentos, aniversários, batizados, gravidez, funerais etc. O indivíduo se classifica em diversos compartimentos, sincrônica ou sucessivamente, e, para passar de um ao outro a fim de poder reunir-se com indivíduos classificados em outros compartimentos, obrigado a submeter-se, do dia do nascimento ao da morte, a cerimônias frequentemente diversas pelas formas, mas semelhante mecanismo. Ora, o indivíduo estava só diante de todos os grupos, ora figurava como membro de um determinado grupo separado de todos. ${ }^{8}$

\section{Ética da Comunhão}

Pode-se dizer que são movidos por uma ética da comunhão os banquetes bíblicos que têm como principal objetivo propagar a partilha solidária mediada pelo cuidado. Como fala Leonardo Boff, ${ }^{22}$ em seu livro Saber Cuidar (2013), é necessário entender o verdadeiro significado do cuidado, só para a partir daí refletir sobre a ética de comunhão que rege os banquetes descritos a seguir: 
"cuidado significa então desvelo, solicitude, diligência, zelo, atenção, bom trato. Estamos diante de uma atitude fundamental, de um modo de ser mediante o qual a pessoa sai de si e centra-se no outro com desvelo e solicitude". ${ }^{22}$

Assim sendo, no corpus analisado foram localizados banquetes que indicam a ética da comunhão: pautada pelos banquetes nas quais valores, conquistas, ideais são partilhados, ou uma ideia de comunidade ou, ainda, a intervenção em favor de alguém ou algum povo, visando a um fim político, à construção de uma esfera de bem comum (quadro 2).

Quadro 2. Ética da comunhão

\begin{tabular}{|c|c|c|c|c|c|}
\hline $\begin{array}{l}\text { Livro, } \\
\text { capítulo, } \\
\text { versículo }\end{array}$ & $\begin{array}{l}\text { Tipo de } \\
\text { banquete }\end{array}$ & Anfitrião & Razão do Banquete & $\begin{array}{l}\text { Público } \\
\text { convidado }\end{array}$ & $\begin{array}{l}\text { Alimentos/ } \\
\text { preparações } \\
\text { consumidos }\end{array}$ \\
\hline $\begin{array}{l}\text { Lucas 22: } \\
17-20\end{array}$ & Partillhar & Jesus & $\begin{array}{l}\text { Mostrar o valor da } \\
\text { comunhão última ceia }\end{array}$ & Apóstolos & Pão e vinho \\
\hline Ester 1:5 & Partilha & Assuero & $\begin{array}{l}\text { Partilhar conquistas } \\
\text { do rei }\end{array}$ & $\begin{array}{l}\text { Todos os } \\
\text { cidadãos da } \\
\text { cidade }\end{array}$ & Não é relatado \\
\hline Ester 1:9 & Partilha & Vasti & $\begin{array}{l}\text { Partilhar as conquistas } \\
\text { do rei }\end{array}$ & $\begin{array}{l}\text { Apenas as } \\
\text { mulheres da } \\
\text { cidade }\end{array}$ & Não relatado \\
\hline Ester 5:6 & Intervenção & Ester & $\begin{array}{l}\text { Suplica ao rei pelo } \\
\text { judeus }\end{array}$ & Rei e Hamã & Não é relatado \\
\hline Ester 8:17 & Comunidade & Ester & $\begin{array}{l}\text { Comemoração dos } \\
\text { judeus pela expiação } \\
\text { do pedido de morte }\end{array}$ & $\begin{array}{l}\text { Todos os } \\
\text { presentes }\end{array}$ & Não é relatado \\
\hline Jó 1:4,5 & Comunhão & $\begin{array}{l}\text { Filhos de } \\
\text { Jó }\end{array}$ & $\begin{array}{l}\text { Socialização entre } \\
\text { entre irmãos e irmãs }\end{array}$ & $\begin{array}{l}\text { Irmãos e } \\
\text { irmãs }\end{array}$ & Não é relatado \\
\hline Mateus14:19 & Intervenção & Jesus & $\begin{array}{l}\text { Saciar a fome } \\
\text { da multidão. } \\
\text { Multiplicação do pão e } \\
\text { do peixe }\end{array}$ & $\begin{array}{l}\text { Servos e } \\
\text { discípulos }\end{array}$ & Pão e peixe \\
\hline
\end{tabular}


As práticas rituais que envolvem a partilha do alimento são encontradas em escrituras bíblicas. Com essa finalidade, os banquetes são organizados como ligação entre o anfitrião e os convivas. Destacamos como exemplos o milagre da multiplicação do pão e dos peixes, realizado no Monte das Oliveiras, a Grande Ceia e o banquete da rainha Ester. A seguir, podem-se observar breves relatos sobre tais fragmentos.

Jesus Cristo, após receber notícia da morte de João Batista, encontra um barco e vai para o deserto, porém seus discípulos e multidão vão a seu encontro. Jesus, sensibilizado com tamanha devoção, cura os enfermos presentes. Ao final, um dos discípulos pede a Jesus para deixar seu povo voltar às aldeias para comer, pois ali não havia alimento suficiente para todos. Jesus então pediu ao discípulo os pães e peixes que tinham, segurou em suas mãos, olhou para o céu, abençoou e devolveu aos seus discípulos, que por sua vez os repassaram à multidão e todos comeram que se saciaram:

E, tendo mandado que a multidão se assentasse sobre a erva, tomou os cinco pães e os dois peixes, e, erguendo os olhos ao céu, os abençoou, e, partindo os pães, deu-os aos discípulos, e os discípulos àmultidão. E comeram todos, e saciaram se; levantaram dos pedaços, que sobejaram, doze alcofas cheias (Mateus 14,19:20).

Jesus fez uma grande ceia e convidou seus apóstolos mais chegados para a celebração de sua morte, que estava por vir. Sua morte ofereceria a redenção dos pecados humanos e abriria as portas para o reino por vir. Este pacto é selado pela transubstanciação, segundo a crença cristã católica, do vinho e do pão em sangue e corpo de Cristo. "E, tomando o cálice, e havendo dado graças, disse: Tomai-o, e reparti-o entre vós; [...] E, tomando o pão, e havendo dado graças, partiu-o, e deu-lho, dizendo: Isto é o meu corpo, que por vós édado; fazei isto em memória de mim”(Lucas 22:17-20).

A rainha Ester, por sua vez, preocupada com o que poderia acontecer com todos de sua linhagem, preparou um banquete para o rei Assuero e também convidou Hamã. Tal banquete tinha uma única intenção: apelar pela vida dos judeus, o seu povo. Foi nessa cerimônia que Ester revelou sua identidade como judia para o rei. Após apelar pela vida dos judeus, o rei cancelou sua ordem, dada a pedido de Hamã, para matar todos os judeus e o condenou à forca por ter ultrajado Ester dentro do seu próprio palácio:

Respondeu Ester: Se bem te parecer, venha o rei e Hamã, hoje, ao banquete que eu preparei ao rei. Então, disse o rei: fazei apressar a Hamã, para que atendamos ao que Ester deseja. Vindo, pois, o rei e Hamãao banquete que Ester havia preparado, disse o rei a Ester, no banquete do vinho: Qual éa tua petição? Esse te dará. Que desejas? Cumprir-se-á, ainda que seja metade do reino (Ester 5:6).

Atentando para o significado da palavra "cuidado", conforme enunciada por Boff, ${ }^{22}$ a partilha de alimentos trazida à tona pelos banquetes elencados acima funda uma ética da comunhão porque, ao partilhar, doa-se pelo outro com atitude atenta e zelo (Jesus e seu sacrifício, Jesus e a atenção 
com os famélicos, Ester e a compaixão com seu povo). A comunhão marcada pela partilha de alimentos, além de marcar uma identificação e compromisso solidário, marca uma preocupação diligente com o bem-estar do outro: a partilha do pão material.

Na multiplicação dos pães e peixes, Jesus, ao penalizar-se com seus seguidores famélicos, que mesmo assim caminharam uma longa distância ao seu encontro, operou o milagre da multiplicação dos alimentos para suprir a necessidade de seu povo. A fome era implacável no período ao qual o texto bíblico se refere. ${ }^{9,23}$ Assim sendo, as parábolas que Jesus contava, apesar de ser filho de carpinteiro, não tomavam por base a atividade da carpintaria ou da marcenaria, mas atividades como a lavra, a semeadura e a ceifa, a economia, pecuária, o pastoreio, as vindimas e a preparação do pão.

Eram muitos aqueles que se interessavam pela ética que Cristo vinha propor e pelas profecias que anunciava como se, simultaneamente, ele fosse fundador de um reino de abundância, um reino de cereais. ${ }^{24}$ As atenções das massas esfomeadas estavam viradas para todos os profetas que aparecessem, sempre com uma solução mais prática: porque a verdade é que o pão celestial não era suficiente, as massas precisavam do pão terreno. ${ }^{24}$ Convém não esquecer que uma das mais antigas tarefas dos profetas judaicos era cuidar da alimentação do seu povo. ${ }^{24}$ Cuidar, sobretudo, do seu pão.

As pessoas viviam num mundo em que os especuladores retinham os cereais e no qual o Estado e o imperador se serviam do pão para fins políticos, dando alimento a quem apoiasse o seu poder. Assim sendo, Jesus oferecia pão basicamente por dois motivos: (1) para de certa maneira demonstrar que perspectivas seu reinado traria em relação à fome material, onde essas ações o levariam a conquistar e ter confiança naquele povo; e também como (2) forma de cuidado. Chegavam até ele pessoas sofrendo das mais terríveis doenças, desesperadas e esfomeadas. Cristo mergulhava de tal forma no interior do sofrimento daquelas pessoas que era insuportável não ajudar. Curava-os e dava-lhes pão. ${ }^{24}$ Sua partilha foi fundada em um ato amoroso, sendo o amor uma abertura ao outro e uma "com-vivência" e "co-munhão". ${ }^{22}$

Além do pão como alimento físico, como era o maná, ele destaca que aquele pão, enquanto palavra, verbo, tinha o poder de conceder a eternidade espiritual: aquele que comesse do pão, ou seja, que comungasse daquele momento ritual da palavra, lograria a almejada vida eterna: "Quem come dele não morrerá"(Jó, 6 48:50). Isso fica evidente com o ritual da Última Ceia.

Este banquete ganhou essa denominação devido não sóa partilha de Jesus com seus discípulos e servos, mas sobretudo pela divisão do pão espiritual: o reino de Deus. Jesus traz àtona a comensalidade como prática unificadora e fundante de um ritual de comunhão radical, onde seu próprio corpo, simbolicamente, éoferecido aos convivas, conforme o ritual cristão. ${ }^{25}$

Fundou assim uma comunidade da igualdade. A comensalidade impulsionou o movimento à mesa e buscou a consolidação das ideias propulsoras da adesão ao convívio. Neste caso, buscaram- 
se as percepções concordantes: o ideal cristão. A comunidade acabou por não constituir aquilo que Jacques Rancière ${ }^{26}$ denomina "comunidade política": onde os sujeitos, mesmo com suas percepções individuais discordantes, interagem não em busca de um entendimento, mas para trazer à tona um dissenso. Esse ato funda um regime político por incentivar a multiplicidade de manifestações dentro da comunidade. Destaca-se, portanto, uma sociabilidade alimentar pautada em uma ideia de imunologia: identificar iguais e distingui-los dos diferentes como forma de proteção, anticorpos contra as influências externas, reforço do vínculo interno da comunidade, como sugere Peter Sloterdijk. ${ }^{27}$

É nesse momento também que Jesus consagra pela primeira vez a Eucaristia. Correia ${ }^{28}$ levanta do texto questões como: que tipo de refeição é esta em que Jesus come com os seus discípulos e na qual institui a Eucaristia? Uma refeição pascal ou uma refeição de despedida? Sabe-se que, muito antes da instituição da Eucaristia, falava-se do ato de comer à mesa e seus significados como um ato quase tão antigo como a humanidade, assim como dos sacrifícios rituais. Pensar em respostas para as perguntas chega a motivar nosso olhar para tentar entender esse tipo de partilha.

Correia $^{28}$ responde que não se tratou de Ceia Pascal, mas de uma refeição de adeus ou despedida realizada em um ambiente familiar e apropriado. Na ocasião, Jesus fez comunicações íntimas aos seus discípulos e revelou-lhes as suas últimas vontades. Partilhando o pão e o vinho, e atribuindo-lhes naquela ceia um significado ritual, (o pão significando Seu corpo e o vinho Seu sangue) Jesus instituiu a Eucaristia:

E, tomando o pão, e havendo dado graças, partiu-o, e deu-lho, dizendo: Isto éo meu corpo, que por vós édado; fazei isto em memória de mim. Semelhantemente, tomou o cálice, depois da ceia, dizendo: Este cálice éo novo testamento no meu sangue, que éderramado por vós (Lucas 22:19-20).

Portanto, a Última Ceia é promulgada como ética da comunhão porque Jesus partilhou com seus discípulos o que deveria ter real valor e importância em sua vida e na da humanidade, um ideal, instituindo o ato de comer do "pão da vida"aquele que poderia conceder a vida eterna.

Para os católicos, a instrução Eucharisticum Mysterium, sobre o culto da sagrada Eucaristia, apresenta três de suas dimensões inseparáveis: a do sacrifício, a do memorial e a do banquete. Diz o seguinte: a missa ou Ceia do Senhor é ao mesmo tempo e de forma inseparável - sacrifício no qual se perpetua o sacrifício da cruz; memorial da morte e da ressurreição do Senhor, que disse: "Fazei isto em memória de mim"(Lucas 22:19); banquete sagrado, em que, pela comunhão do corpo e sangue do senhor, o povo de Deus participa nos bens do sacrifício pascal, renova a nova aliança entre Deus e os homens selada de uma vez para sempre com o sangue de Cristo, e prefigura e antecipa na fé e na esperança o banquete escatológico no reino do Pai anunciando a morte do Senhor até que venha. ${ }^{29}$ 
A partilha da rainha Ester revelava-se com duas intenções indiretamente familiares como as de Cristo: tinha o desejo de destacar-se como líder, assim como Cristo, mas tinha como principal objetivo a liberdade de seu povo, os judeus, e a constituição de uma política de civilização para os mesmos. Edgar Morin ${ }^{30}$ formulou imperativos de uma política de civilização, que podem ser auxiliares para refletirmos sobre os ensejos de Ester sobre o povo judeu: um povo escravizado, perseguido e assassinado por outros. Os imperativos que Morin ${ }^{27}$ formulou foram: (1) solidarizar (contra a atomização e a compartimentalização); (2) retornar às origens (contra a anonimização); (3) conviver (contra a degradação da qualidade de vida); e (4) moralizar (contra a irresponsabilidade e o egocentrismo). A rainha Ester, a partir da narrativa bíblica, demonstrou o desejo de uma nova cultura para os judeus, a promoção de atos solidários, uma convivialidade igual, respeito, união, cordialidade, ou seja, práticas de bem, ações quase inexistentes para com judeus.

Nota-se, na ética da comunhão, que todos os banquetes vinham acompanhados de intenções, como todos os atos da vida humana. Mas, em tais ocasiões, o que se observa é que tais atitudes pautavam-se, sobretudo, por um ideal comunitário. Não sabemos o que se consumiu no banquete da rainha Ester, compreende-se apenas que os únicos participantes foram Assuero e Hamã. Sabemos que, após Assuero atender ao pedido de sua rainha, os judeus comemoraram o fim do decreto de sua morte, participando desse banquete todos os que se alegraram com a notícia sobre os judeus.

Também em toda província e em toda cidade aonde chegava a palavra do rei e a sua ordem, havia entre os judeus alegria e regozijo, banquetes e festas, e muitos, dos povos da terra, se fizeram judeus, porque o temor dos judeus tinha caído sobre eles. (Ester, 8:17)

A ética da comunhão cria uma esfera de partilha de valores, conquistas, ideais (Última Ceia), de cuidado em favor de alguém ou algum povo (milagre dos pães e intervenção de Ester), visando a um fim político, ou seja, a construção de uma esfera de bem comum, onde os alimentos denotam um sinal de comunhão, seja de um pão físico, seja espiritual. A ética da comunhão é explicitamente abraçada pelo cuidado, busca unir pessoas e recriar, pela linguagem amorosa, o sentimento de benquerença e de pertença. ${ }^{22}$ Jesus e Ester, a partir da narrativa, parecem não medir esforços para tentar estabelecer uma nova esfera de bem na humanidade. Suas ações solidárias parecem prezar pelo ensino e/ou criação de novos significados e valores humanos.

\section{Ética do Poder}

Pode-se dizer que são movidos por uma ética do poder os banquetes que, a partir da narrativa bíblica, têm como principal objetivo expressão de poder supremo. Como comenta Albert: ${ }^{31}$ 
$O$ banquete toma um significado e desempenha um papel essencial nas sociedades antigas: ele constitui o meio, em tempos de paz, de glorificar o grande poder daquele que o oferece, quer seja ele um personagem poderoso ou uma cidade, e representa uma ocasião de redescobrimento da vida coletiva e de afirmação de uma identidade cultural. ${ }^{31}$

No corpus analisado, expressam-se como ética de poder aqueles banquetes de caráter político que se apresentavam com a função de instituir acordos, alianças ou honrar alguém, expressar poder pela produção de imagens de fartura e marcar distinções hierárquicas entre soberanos e servos.

Pode-se ressaltar os seguintes banquetes como ética de poder: o de Abimeleque, o de Davi, o do rei Assuero, o de Eliseu e o de Belsazar. A seguir, um breve relato sobre alguns desses banquetes (quadro 3).

Quadro 3. Ética do poder

\begin{tabular}{|c|c|c|c|c|c|}
\hline $\begin{array}{l}\text { Livro, } \\
\text { capítulo e } \\
\text { versículo }\end{array}$ & $\begin{array}{l}\text { Tipo do } \\
\text { banquete }\end{array}$ & Anfitriões & Razão do banquete & $\begin{array}{l}\text { Público } \\
\text { convidado }\end{array}$ & $\begin{array}{l}\text { Alimentos/ } \\
\text { preparações } \\
\text { consumidos }\end{array}$ \\
\hline $\begin{array}{l}\text { Gênesis } \\
26: 30\end{array}$ & Aliança & Abimeleque & $\begin{array}{l}\text { Aliança entre Isaque e } \\
\text { Abimeleque por Isaque } \\
\text { ter sido expulso de } \\
\text { Gerar }\end{array}$ & $\begin{array}{l}\text { Isaque e } \\
\text { Abimeleque }\end{array}$ & Não é relatado \\
\hline $\begin{array}{l}\text { Samuel II } \\
3: 20\end{array}$ & Acordo & Davi & $\begin{array}{l}\text { Acordo entre Davi e } \\
\text { Abner para soberania } \\
\text { de Davi sobre todos }\end{array}$ & $\begin{array}{l}\text { Davi, Abner } \\
\text { e soldados } \\
\text { presentes }\end{array}$ & Não é relatado \\
\hline Reis II 6:26 & $\mathrm{Paz}$ & Eliseu & $\begin{array}{l}\text { Estabelecer } \\
\text { cordialidade entre o } \\
\text { rei da Síria e Eliseu }\end{array}$ & Soldados & Não é relatado \\
\hline Ester 1:5 & Poder & Assuero & $\begin{array}{l}\text { Demonstração de } \\
\text { riquezas aos servos }\end{array}$ & $\begin{array}{l}\text { Todos os } \\
\text { cidadãos de } \\
\text { Susã }\end{array}$ & Não é relatado \\
\hline Daniel 5:1 & Honra & Belsazar & $\begin{array}{l}\text { Honrar os melhores } \\
\text { soldados do rei }\end{array}$ & Soldados & Não érelatado \\
\hline
\end{tabular}


Isaque, como fiel servo de Deus, obedecendo sempre a suas ordens, reside em Gerar por tempo determinado, nas terras do rei Abimeleque. Lá, Isaque engrandeceu e começou a adquirir muitas terras, animais, trabalhadores e água. Abimeleque, com medo do crescimento de Isaque, expulsa-o de suas terras. Percebendo a posses que Isaque adquiria por enaltecer um Deus, Abimeleque foi ao seu encontro juntamente com um amigo e o príncipe do seu exército, e pediu a Isaque para criarem uma aliança de paz, que selaram com um banquete.

E eles disseram: Havemos visto, na verdade, que o Senhor écontigo, por isso dissemos: Haja agora juramento entre nós, entre nós e ti; e façamos aliança contigo. Que não nos faça mal, como nós te não temos tocado, e como te fizemos somente bem, te deixamos ir em paz. Agora tu és o bendito do Senhor. Então lhe fez um banquete, e comeram e beberam (Gênesis 26 28:30).

Is-Bosete acusou Abner de ter tomado para si uma concubina de Saul, chamada Rispa, filha de Iái. Abner era o comandante do exército de Saul e eram primos. Abner tomou como insulto a acusação de Is-Bosete e foi ao encontro de Davi, inimigo de Saul, que decidiu unir-se a ele no domínio do reino de Davi pela soberania. Após oferecer-se como aliado a Davi, o próprio selou o acordo entre eles num banquete:

[...] e falou também Abner aos de Benjamim; e foi também Abner aos de Davi, em Hedrom, tudo o que era bom aos olhos de Israel e aos olhos de toda a casa de Benjamim. E foi Abner a Davi, em Hedrom, e vinte homens com ele; e Davi fez um banquete a Abner e aos homens que com ele estavam (Samuel II 3: 19,20).

O profeta Eliseu, por ordem de Deus, viveu muitos anos longe do reinado dos Sírios. Certo dia, um servo do rei comentou que existia um profeta que sabia o que ele dizia no seu quarto de dormir. O rei, curioso com o profeta Eliseu, enviou em sua busca cavalos, carros e um grande exército. Eliseu, quando os avistou, pediu-Lhe uma atitude, então Deus fez surgir fogo ao redor de Eliseu. Eliseu orou e pediu a Deus para cegá-los para que ele pudesse levá-los ao meio da Samaria. Chegando a Samaria, Deus ordenou que Eliseu desse comida e bebida a todos e os deixasse ir para seu Senhor:

Mas ele disse: Não ferirás; tu os que tomasses prisioneiros com a tua espada e com o teu arco? Põe-lhes diante pão e água, para que comam e bebam, e se vão para seu senhor. E apresentou-lhes um grande banquete, $e$ comeram e beberam; e os despediu e foram para seu senhor; e não entraram mais tropas de sírios na terra de Israel (Reis II 6: 22,23). 
O rei Assuero, querendo exibir suas riquezas e glória de seu reino, ofertou um banquete no seu terceiro ano de reinado a todos os seus príncipes, servos e nobres, para mostrar toda sua grandeza: "no terceiro ano do seu reinado, fez um banquete a todos os seus príncipes e seus servos, estando assim perante ele o poder da Pérsia e Média e os nobres e príncipes das províncias" (Ester 1:3).

O rei Belsazar, após assumir o trono de seu pai Nabucodonosor, em virtude de comemorar seus mais honrados soldados do exército, realizou um banquete para eles, onde comeu e bebeu na presença de todos. Durante esse banquete, aconteceu um episódio em que alguém escreveu nas paredes do palácio com dedos sujos de sangue alguma profecia que assombrou o rei, que acabou indo em busca de Daniel para tentar interpretar a mensagem: "O rei Belsazar deu um grande banquete a mil dos seus senhores, e bebeu vinho na presença dos mil" (Daniel 5:1).

Os banquetes destacados atentam para uma observação de Albert: ${ }^{31}$ a mesa é a ocasião para um tipo particular de sociabilidade. Como local de tomada de decisões, de demonstração de força, de integração e de exclusão, de hierarquização ou de nivelamento, a mesa é uma das ferramentas mais sutis e mais eficazes.

Abimeleque, em seu banquete, queria fortalecer sua autoridade nas suas propriedades aliandose a Isaque, porque foi ele que adquiriu mais posses do que qualquer um nos últimos tempos. Davi consolidou Abner como um aliado para futura unificação de reinado, e Eliseu criou uma forma de acordo de paz para ele com a Assíria, para sua proteção. Assuero impressionava por sua fartura à mesa, assim como o pai de Belsazar, Nabucodonosor. Todos eles, juntos, executavam rituais em que se distinguiam de seus súditos.

A mesa posta pelos dois reis, Abimeleque e Davi, chama atenção para finalidades parecidas: reforço de uma aliança em que atribuem ao alimento o papel de testemunho dos acordos, compartilhamento de mesmos interesses, interesses, estabelecidos entre seus convivas; e união, pelo mesmo sentido político. Sentar-se à mesa não era um gesto inofensivo. ${ }^{31}$ Eliseu, no entanto, não era um rei, mas um profeta que servia a um Deus; esse Deus o escutava e o medo da situação na qual foram colocados os soldados que o procuravam atribuiu-lhe uma imagem de poder.

Não sabemos o que foi consumido nesses banquetes, mas sabemos que além dos anfitriões deles, Abimeleque, Davi e Eliseu, estavam participando soldados que acompanhavam seus reis na firmação dos acordos.

Os banquetes da AntiguidadeClássica possuíam divisões bem distintas. A primeira etapa do banquete era o deipnon, seguido do symposion. No deipnon, o anfitrião servia as carnes assadas e/ ou grelhadas provenientes de sua criação, acompanhadas de pão. Na sequência, o symposion era definido como uma forma de organização social no qual um grupo de homens expressava sua identidade através do ritual e beber e comer. ${ }^{32}$ 
François Lissarrague ${ }^{33}$ descreve como seria um simpósio arcaico:

[...] é um espaço fechado, limitado a um pequeno número de convivas iguais entre si, que se bastam a si mesmos. O prazer do simpósio associa, combinando-os, o vinho, a música, a palavra e o espetáculo: trata-se unicamente do espetáculo proporcionado pelos convivas, pela decoração da sala em que se reúnem e, evidentemente, pelas taças que circulam nas mãos dos que bebem.

Uma partilha diretamente com o rei representava a coesão de igualdade e cidadania entre os convivas. O banquete privado que o rei Belsazar realizou para seus soldados é tido como exemplo. A passagem bíblica relata que o rei partilhou com seus soldados sua taça de vinho. Dividir a taça de vinho com o rei era sinal de unidade e interação com os convivas. Alimentar os convivas estabelecia uma forma de companheirismo que, em retorno, atribuía deveres a essa dádiva alimentar. ${ }^{31}$ Candido $^{32}$ relata que, na Roma Antiga, os banquetes eram momentos em que se buscava reforçar valores como a unidade, através da comensalidade. Portanto, a refeição pública era investida de uma carga política que evidenciava não somente o grande poder do príncipe, pela iniciativa do festim, mas também a organização da sociedade, representada dessa maneira.

Logo, esses banquetes participavam como ética de poder, pelo fato de ocorrerem acordos selados entre soberanos, produção de imagens da fartura e do excesso e, sobretudo, por atentar para uma das características mais contraditórias que perfazem os rituais de comensalidade: o estabelecimento simultâneo de igualdade e hierarquia.

Ao mesmo tempo que, ao comungar, deseja-se estabelecer igualdade, o ritual é permeado de regras que distinguem os convivas hierarquicamente, seja no reparto, seja nos lugares tomados. Os banquetes regidos pela ética do poder são cercados de sinais para determinar a posição social e política de cada um.

\section{Considerações finais}

Ao refletir e analisar o que constitui a ética alimentar nos banquetes bíblicos, pode-se perceber que as análises aqui realizadas, a partir de um dos documentos formadores da cultural ocidental, atentam para três tipos de comportamento que regiam os atos de partilha de alimentos: (1) a ética da passagem, que serve como signo de uma mudança na vida coletiva ou individual como casamentos (Jacóe Raquel, Bodas de Canaã, Assuero e Ester), aniversários (Faraóe Herodes) e mortes (Páscoa e Nabal), mediadas pela comensalidade, que por sua vez, ordena, classifica, estabelece as prioridades, dando sentido a estes marcos da vida social; (2) a ética da comunhão, que cria uma esfera de partilha 
de valores, conquistas, ideais (Última Ceia), de cuidado em favor de alguém ou algum povo (milagre dos pães e intervenção de Ester), visando a um fim político, ou seja, a construção de uma esfera de bem comum, onde os alimentos denotam um sinal de comunhão, seja de um pão físico, seja espiritual; e por fim, (3) a ética do poder, onde partilhas engendram relações de acordo (Abimeleque, Davi, Elizeu, Belsazar), de demonstração do poder, via produção de imagens de fartura (Assuero) e desenham distinção entre o soberano e seus súditos (todos).

Sobre a caraterização dos banquetes, pode-se dizer que (1) sobre o consumo, os alimentos praticamente não são mencionados em nenhum banquete, com a exceção das passagens da Última Ceia e a multiplicação dos pães. Algumas hipóteses foram apresentadas durante o texto para pensar tal omissão, e outras podem ser pensadas e analisadas em estudos futuros. Sobre os (2) protocolos e (3) o público, que variavam em função da motivação para realização dos banquetes, pode-se afirmar que uma constante nos banquetes é o fato de não existir uma relação de igualdade entre os convivas, e ainda que a comensalidade busque estabelecer uma ideia de horizontalidade, a hierarquia em algum momento emerge no contexto da partilha; sobre as motivações (4), podem ser sintetizadas sob as três éticas - passagem, comunhão e poder.

Além disso, acredita-se que as éticas acima descritas podem auxiliar um estudo sobre os ritos de comensalidade na sociedade atual. A ética da comunhão, por exemplo, poderia dar apoio à seguinte reflexão: como uma sociedade influenciada pelo ideal cristão, num país como o Brasil, compreende a divergência entre o ideal da ética da comunhão apresentado na Bíblia e um inconsciente cristão e a resistência a algumas políticas de Segurança Alimentar e Nutricional, sobretudo aquelas relacionadas à transferência de renda? Ou seja, como defender o ideal da partilha e da igualdade a partir de um inconsciente religioso e negar este mesmo ideal no momento de concretizá-lo enquanto política de Estado? Tais políticas, em verdade, fundam hoje uma espécie de política de civilização, ou seja, a garantia do direito de todos de habitar a mesa comum da humanidade.

Pensar sobre tais questões abre novos olhares em direção ao fenômeno alimentar e, portanto, à ciência que dele mais diretamente se ocupa no mundo atual, a Nutrição. Pensar a alimentação envolve dar atenção não apenas ao componente de função e subsistência que repousa nos alimentos, mas envolve pensar os símbolos, a imaginação coletiva, a sociabilidade, enfim, todas as questões que perpassam o humano. Isso levanta desafios e a necessidade da construção de uma Antropologia da Nutrição. O tema de ética alimentar nos banquetes bíblicos abriria mais possibilidades de estudos relacionados a cultura e sociabilidades. 


\section{Referências}

1. Canesqui AM, Garcia RWD, ORGS. Antropologia e utrição: um diálogo possível. Rio de Janeiro: Editora Fiocruz; 2005. 306 p. Antropologia e Saúde.

2. Nascimento AB. Comida: prazeres, gozos e transgressões. 2. ed. Salvador: Editora EDUFBA; 2007. $291 \mathrm{p}$.

3. Moreira SA. Alimentação e comensalidade: aspectos históricos e antropológicos. Cienc. Cult. 2010; 62(4):23-26.

4. Sellier P. Para conhecer a Bíblia: um guia histórico e cultural. São Paulo: Martins Fontes; 2011. 330 p.

5. Lévi-Strauss C. O pensamento selvagem. Campinas: Papirus; 1989.

6. Almeida JFA. tradutor A Bíblia Sagrada. 2. ed. São Paulo: Sociedade Bíblica do Brasil; 2011.

7. Bauer MW, Gaskell G. Pesquisa qualitativa com texto, imagem e som: um manual prático. Petrópolis: Vozes; 2002. 516 p.

8. Van Gennep A. Os ritos de passagem. Petropólis: Vozes; 2013.

9. Araujo MF. Amor, casamento e sexualidade: velhas e novas configurações. Psicol. Cienc. Prof. 2002; 22(2):70-77.

10. Joannès F. A função do banquete nas primeiras civilizações. In: Flandrin JL, Montanari M. organizadores. História da alimentação. São Paulo: Estação Liberdade; 1998. p. 54-67.

11. Le Houerou LF. Le film um don de soi. 2006 [Internet]. [acesso em: 16 jan. 2015]. Disponível em: http://comitedufilmethnographique.com/wp-content/uploads/2012/07/le-houerou-fab.pdf

12. Montanari M. A fome e a abundância: história da alimentação na Europa. Bauru, SP: EDUSC; 2003.

13. Quellier F. Gula: história de um pecado capital. São Paulo: Editora Senac; 2011.

14. Fontoura DL. Do consumo de luxo à demonstração do laço afetivo: a nova face do casamento. [Trabalho de conclusão de curso]. Porto Alegre: Graduação em Comunicação Social da Universidade Federal do Rio Grande do Sul; 2011.

15. Fernandes AT. Ritualização da comensalidade [Internet]. 1997. [acesso em: 10 fev. 2015]. Disponível em: http://ler.letras.up.pt/uploads/ficheiros/1412.pdf

16. Terrin NA. O rito: antropologia e fenomenologia da ritualidade. São Paulo: Paulus; 2004. Estudos antropológicos.

17. Cavalcante R. A origem do bolo de aniversário. Guia do Estudante [Internet]. 01 ago. 2007. [acesso em: 01 fev. 2015]. Disponível em: http://guiadoestudante.abril.com.br/aventuras-historia/origembolo-aniversario-453995.shtml

18. Gage M, Gage J. Birthday cakes: history \& recipes. New England Recipes [Internet]. 2012. [acesso em: 10 jan. 2015]. Disponível em: http://www.newenglandrecipes.org/html/birthday-cake.html 
19. Mithen SA Pré-história da mente: uma busca das origens da arte, da religião e da ciência. São Paulo: Editora Unesp; 2002.

20. Burkert W. Religião grega na época clássica e arcaica. Lisboa: Serviço de Educação, Fundação Calouste Gulbenkian; 1993.

21. Martins ICC. A festa da Páscoa entre hebreus e cristãos. Igreja Metodista: região Missionária do Nordeste [Internet]. Disponível em: http://remne.metodista.org.br/conteudo.xhtml?c=10160

22. Boff L. Saber cuidar. Petropólis, RJ: Vozes; 2013.

23. Laurioux B. Manger au moyen âge. Paris: Hachette Litèrratures; 2002.

24. Jacob EH. Seis mil anos de pão. São Paulo: Nova Alexandria; 2003.

25. Betto F. Politícas do corpo. Motrivivência: Revista de Educação Física, Esporte e Lazer 2000; 15. Disponível em: https://periodicos.ufsc.br/index.php/motrivivencia/article/view/5583/5352

26. Rancière J. A partilha do sensível: estética e política. São Paulo: Editora 34; 2009.

27. Sloterdijk P. A loucura de Deus: do combate dos três monoteímos. Lisboa: Relógio D’água; 2009.

28. Correia SAJ. A Eucaristia na Bíblia e a Bíblia na Eucaristia. Theologica 2a série 2008; 43(1):195-213.

29. Sagrada Congregação dos Ritos: Instrução Eucaristicum Mysterium. Acta Apostolicae Sedis 1967; 59(1):539-573. Disponível em: http://www.vatican.va/archive/aas/documents/AAS-59-1967-ocr.pdf

30. Morin E. A alimentação. In: Morin E. A via para o futuro da humanidade. Rio de Janeiro: Bertrond Brasil; 2013. Cap. 4.

31. Albert JM. Ás mesas do poder: dos banquetes ao Eliseu. São Paulo: Editora Senac; 2011.

32. Candido RM. Práticas alimentares no Mediterrâneo antigo. Rio de Janeiro: NEA/UFRJ; 2012.

33. Lissarague F. Un flot D'images. Une esthétique du banquet grec. Paris: Adam Biro; 1987.

Recebido: 08/4/2015

Revisado: 02/9/2015

Aceito: $10 / 10 / 2015$ 